\title{
Correction: Maternal deprivation induces alterations in cognitive and cortical function in adulthood
}

Sarine S. Janetsian-Fritz' ${ }^{1}$ Nicholas M. Timme', Maureen M. Timm¹, Aqilah M. McCane', Anthony J. Baucum², Brian F. O'Donnell ${ }^{3}$ and Christopher C. Lapish ${ }^{1,4,5}$

Correction to: Translational Psychiatry; https://doi. org/10.1038/s41398-018-0119-5; published online 27 Month 2018.

The original version of this Article omitted the author Maureen M. Timm from the Department of Psychology, Indiana University-Purdue University Indianapolis, Indianapolis, IN, USA.
Furthermore affiliation 1 was inadvertently repeated in the affiliation list. These errors have now been corrected in the HTML and PDF versions of the Article.

Published online: 31 July 2018

Correspondence: Sarine S. Janetsian-Fritz (sjanetsi@iupui.edu)

'Department of Psychology, Indiana University-Purdue University Indianapolis, Indianapolis, IN, USA

${ }^{2}$ Department of Biology, Indiana University-Purdue University Indianapolis,

Indianapolis, IN, USA

${ }^{3}$ Department of Psychological and Brain Sciences, Indiana University,

Bloomington, IN, USA

${ }^{4}$ Indiana University School of Medicine Stark Neuroscience Institute,

Indianapolis, IN, USA

${ }^{5}$ Indiana University-Purdue University Indianapolis School of Science Institute

for Mathematical Modeling and Computational Sciences, Indianapolis, IN, USA

(c) The Author(s) 2018

(c) (i) Open Access This article is licensed under a Creative Commons Attribution 4.0 International License, which permits use, sharing, adaptation, distribution and reproduction in any medium or format, as long as you give appropriate credit to the original author(s) and the source, provide a link to the Creative Commons license, and indicate if changes were made. The images or other third party material in this article are included in the article's Creative Commons license, unless indicated otherwise in a credit line to the material. If material is not included in the article's Creative Commons license and your intended use is not permitted by statutory regulation or exceeds the permitted use, you will need to obtain permission directly from the copyright holder. To view a copy of this license, visit http://creativecommons.org/licenses/by/4.0/. 